\title{
SEQUENTIAL INHIBITION OF SEXUAL RECEPTIVITY BY PROGESTERONE IS PREVENTED BY A PROTEIN SYNTHESIS INHIBITOR AND IS NOT CAUSALLY RELATED TO DECREASED LEVELS OF HYPOTHALAMIC PROGESTIN RECEPTORS IN THE FEMALE RAT ${ }^{1}$
}

\author{
BRUCE PARSONS AND BRUCE S. MCEWEN
}

The Rockefeller University, New York, New York 10021

\begin{abstract}
In the estrogen-primed ovariectomized female rat, the administration of progesterone facilitates sexual receptivity and activates proceptivity for many hours. If the progesterone dose is large (e.g., $2.5 \mathrm{mg}$ ), a refractory period follows, during which time animals are less sensitive to additional progesterone. This refractory period has been termed "sequential inhibition" and has been correlated previously with decreased levels of cytosol progestin receptors in the mediobasal hypothalamuspreoptic area (MBH-POA).

Our present results indicate that the "sequential inhibition" of mating behavior by progesterone appears to involve a protein synthetic step that is not related causally to decreased levels of cytosol progestin receptors in the MBH-POA. Animals which received subcutaneous injections of the protein synthesis inhibitor, anisomycin $(100 \mathrm{mg} / \mathrm{kg}$ in saline), $15 \mathrm{~min}$ prior to and again $3 \mathrm{hr}$ after progesterone $(2.5 \mathrm{mg}$ in propylene glycol) treatment, displayed greater sexual receptivity at $24 \mathrm{hr}$ than did animals which received subcutaneous saline injections. However, cytosol progestin receptor levels in the MBH-POA of animals which received anisomycin plus progesterone were decreased at $24 \mathrm{hr}$, relative to animals which received saline plus progesterone. Anisomycin did not produce positive or negative behavioral effects at $24 \mathrm{hr}$ when administered $15 \mathrm{~min}$ prior to and again $3 \mathrm{hr}$ after propylene glycol, suggesting that the behavioral effects of anisomycin appear to be related to selective blockade of progesterone action.

In separate experiments, we administered single subcutaneous injections of anisomycin at various times relative to progesterone $(2.5 \mathrm{mg})$ treatment. According to the time course of effective anisomycin application, the presumed protein synthesis which is responsible for the inhibition of mating behavior occurs between 3 and $13 \mathrm{hr}$ after the administration of progesterone.
\end{abstract}

During the rat estrous cycle, a $36-$ to $48-\mathrm{hr}$ rise in plasma estradiol levels precedes a peak of plasma progesterone (Smith et al., 1975). Progesterone rapidly activates sexual proceptivity (Beach, 1976), such as hopdarting and ear wiggling, and rapidly facilitates sexual receptivity as measured by the lordosis quotient and lordosis quality score (Ball, 1937; Hardy, 1972; KubliGarfias and Whalen, 1977). Subsequently, progesterone may well be involved in the termination of proceptivity

\footnotetext{
' This work was supported by National Institutes of Health, National Research Service Award 7524 from the National Institute of General Medical Sciences (B. P.), Research Grant NS-07080 (B. S. M.), and by Institutional Grant RF70095 from the Rockefeller Foundation for research in reproductive biology. We would like to thank Dr. 'Thomas C. Rainbow and Dr. Lewis Krey for their helpful comments on the manuscript.
}

and receptivity on the day of estrus of the rat reproductive cycle (Morin, 1977).

In the estrogen-primed ovariectomized female rat, the administration of progesterone activates proceptivity and facilitates receptivity for many hours (Meyerson, 1972; Hardy and DeBold, 1971; Boling and Blandau, 1937). If the progesterone $(\mathrm{P})$ dose is large (e.g., $2.5 \mathrm{mg}$ ), a refractory period ensues, during which time animals are behaviorally less sensitive to additional P (Zucker, 1966; Powers and Moreines, 1976; Blaustein and Wade, 1977; Blaustein and Feder, 1979). This refractory period has been termed "sequential inhibition" (Powers and Moreines, 1976). This period of decreased behavioral sensitivity to $P$ has been correlated previously with decreased levels of cytosol progestin receptors in those areas of the brain known to mediate feminine sexual behavior, the mediobasal hypothalamus-preoptic area (MBH-POA), in both 
guinea pig (Blaustein and Feder, 1979) and rat (Moguilewsky and Raynaud, 1979; Schwartz et al., 1979; Parsons et al., 1981a). We now report that "sequential inhibition" of mating behavior by progesterone appears to involve a protein synthetic step that is not related causally to decreased cytosol progestin receptor levels in the MBHPOA. A large portion of the protein synthesis which appears to be essential for the inhibition of mating behavior occurs between 3 and $13 \mathrm{hr}$ after the administration of progesterone.

\section{Materials and Methods}

The experimental design for our investigations is summarized in Figure 1. Sexually inexperienced SpragueDawley female rats (200 to $225 \mathrm{gm}$ ) and sexually vigorous Long Evans male rats (250 to $300 \mathrm{gm}$ ) were obtained from Charles River Laboratories and were housed in temperature-controlled rooms with reversed day-night lighting (for details, see Parsons et al., 1980). Females ovariectomized for 5 to 8 days received a $5-\mathrm{mm}$ Silastic capsule containing crystalline $17 \beta$-estradiol, diluted $1: 9$ with cholesterol, at $-72 \mathrm{hr}$. These capsules have been shown to produce estradiol levels in serum which are comparable to those seen in intact animals on proestrus (McGinnis et al., 1981). All females received subcutaneous injections of $\mathrm{P}$ (2.5 $\mathrm{mg}$ in propylene glycol) or of propylene glycol $(\mathrm{PG})$ at $0 \mathrm{hr}$. Females also received subcutaneous injections of the protein synthesis inhibitor, anisomycin (Pfizer Diagnostics), dissolved $20 \mathrm{mg} / \mathrm{ml}$ in saline or of saline (Rainbow et al., 1980). Anisomycin or saline was administered $15 \mathrm{~min}$ prior to, and again 3 hr after, P or PG treatment. Twenty-four hours after P or PG treatment, some animals were sacrificed for cytosol progestin receptor measurements. All of the remaining animals received a subcutaneous injection of progesterone $(0.5 \mathrm{mg})$ and were given mating tests $4 \mathrm{hr}$ later $(28$ $\mathrm{hr})$. Each female was allowed 10 mounts by an experienced male rat.

The lordosis quotient (LQ) was calculated as: No. lordoses/No. mounts $\times 100$. The lordosis quality (LS) was measured as defined by Hardy and DeBold (1971): $0,1,2,3$-representing no lordosis, light, moderate, and full dorsoflexion, respectively. The LS was computed as: $\Sigma \mathrm{LS} / 10$. All behavioral results are means \pm SEM. Cyto- sol progestin receptor levels in MBH-POA and pituitary were quantified using the synthetic progestin, ${ }^{3} \mathrm{H}-\mathrm{R} 5020$, as the radioligand for an in vitro assay as described by MacLusky and McEwen (1978, 1980). Briefly, aliquots $(400 \mu \mathrm{l})$ of cytosol were incubated with $200 \mu \mathrm{l}$ of TEGD buffer (10 mM Tris, $1.5 \mathrm{~mm}$ disodium EDTA, 10\% (v/v) glycerol adjusted to $\mathrm{pH} 7.4$ with hydrochloric acid, $1 \mathrm{~mm}$ dithiothreitol added on day of use) for 4 to $6 \mathrm{hr}$ at $4^{\circ} \mathrm{C}$ in the presence of $0.4 \times 10^{-9} \mathrm{M}{ }^{3} \mathrm{H}-\mathrm{R} 5020$ (New England Nuclear). This concentration of ${ }^{3} \mathrm{H}-\mathrm{R} 5020$ has been shown to bind specifically progestin receptors and not other macromolecules, such as serum proteins (Blaustein and Feder, 1979; MacLusky and McEwen, 1980). Corrections for nonspecific binding were made using parallel incubations containing $2 \times 10^{-8} \mathrm{M}$ unlabeled R5020 in addition to $0.4 \times 10^{-9} \mathrm{M}^{3} \mathrm{H}-\mathrm{R} 5020$. Bound ${ }^{3} \mathrm{H}-\mathrm{R} 5020$ was measured by gel filtration on Sephadex LH-20 (Pharmacia). Protein in the incubates was determined according to Bradford (1976). Cytosol progestin receptor (CPR) levels are expressed as femtomoles of ${ }^{3} \mathrm{H}-\mathrm{R} 5020$ per $\mathrm{mg}$ of protein; results are means \pm SEM. Each sample consisted of MBH-POA regions or pituitaries from two animals.

\section{Results and Discussion}

It has been shown previously that the administration of $\mathrm{P}$ (2.5 $\mathrm{mg}$ in propylene glycol) to animals which have received Silastic capsules containing $10 \%$ estradiol produces an increase in the lordosis quotient (LQ) and lordosis quality (LS) scores within 3 to $4 \mathrm{hr}$ (Parsons et al., 1981a). This increase is transient and is not observed $22 \mathrm{hr}$ later (Parsons et al., 1981a). As seen in Table I, the administration of progesterone $(0.5 \mathrm{mg})$ at $24 \mathrm{hr}$ produces a lesser facilitation of LQ and LS scores in animals which have received $\mathrm{P}(2.5 \mathrm{mg})$ previously. This observation supports previous findings, referred to as "sequential inhibition" of mating behavior by P (Zucker, 1966; Powers and Moreines, 1976; Blaustein and Wade, 1977; Blaustein and Feder, 1979; Schwartz et al., 1979; Parsons et al., 1981a).

The antibiotic, anisomycin, has been shown previously to inhibit substantially protein synthesis in those areas of the brain known to mediate feminine sexual behavior, the $\mathrm{MBH}$ and POA. When given as a single subcutaneous injection $(100 \mathrm{mg} / \mathrm{kg})$, anisomycin inhibits protein syn-

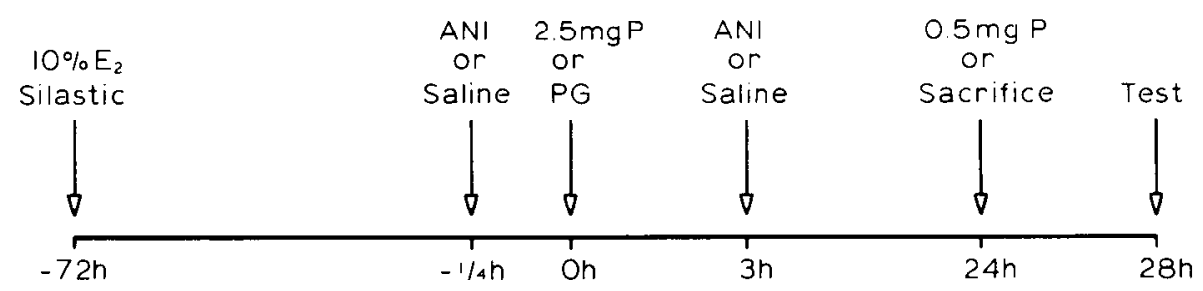

Figure 1. The experimental design for our investigations is summarized in this diagram. Females ovariectomized for 5 to 8 days received a $5-\mathrm{mm}$ Silastic capsule containing $10 \%$ estradiol $\left(E_{2}\right)$ at $-72 \mathrm{hr}$. All females received subcutaneous injections of progesterone $(P, 2.5 \mathrm{mg})$ or of propylene glycol $(P G)$ at $0 \mathrm{hr}$. Females also received subcutaneous injections of the protein synthesis inhibitor, anisomycin $(20 \mathrm{mg} / \mathrm{kg})$, or of saline. Anisomycin $(A N I)$ or saline was administered $15 \mathrm{~min}$ prior to, and again $3 \mathrm{hr}$ after, $\mathrm{P} / \mathrm{PG}$ treatment. Twenty-four hours after $\mathrm{P} / \mathrm{PG}$ treatment, some animals were sacrificed for cytosol progestin receptor measurements. The remaining animals received subcutaneous injections of $P(0.5 \mathrm{mg})$ and were given mating tests $4 \mathrm{hr}$ later (28 hr). 
TABLE I

The effects of anisomycin on the sequential inhibition of receptivity and on cytosol progestin receptor levels

\begin{tabular}{lcccc}
\hline \multicolumn{1}{c}{ Treatment } & Lordosis Quotient & Lordosis Quality & $\begin{array}{c}\text { Progestin Receptors } \\
\text { in MBH-POA }\end{array}$ & $\begin{array}{c}\text { Progestin Receptors } \\
\text { in Pituitary }\end{array}$ \\
\hline PG + saline & $90.0 \pm 3.2^{a}(n=5)$ & $1.72 \pm 0.11^{a}$ & $16.0 \pm 0.4^{b}(n=3)$ & $39.9 \pm 1.6$ \\
PG + anisomycin & $80.0 \pm 11.8^{a}(n=6)$ & $1.55 \pm 0.32^{a}$ & $10.1 \pm 0.9^{b, c}(n=3)$ & $34.5 \pm 1.7$ \\
& & & & \\
P + saline & $65.0 \pm 6.5^{d}(n=12)$ & $1.00 \pm 0.12^{d}$ & $11.4 \pm 0.8^{c}(n=5)$ & $28.3 \pm 1.9$ \\
$\mathrm{P}+$ anisomycin & $92.2 \pm 4.3^{d}(n=9)$ & $1.88 \pm 0.16^{d, f}$ & $9.1 \pm 0.9^{\text {e, }}(n=5)$ & $26.2 \pm 1.8$ \\
\hline
\end{tabular}

"The LQ and LS scores of animals given anisomycin plus PG are not significantly different from animals given saline plus PG.

${ }^{\circ}$ Cytosol progestin receptor levels in MBH-POA of animals which received anisomycin plus PG are significantly different from animals which received saline plus $\mathrm{PG}$.

' $p<0.01$; Student's $t$ test.

${ }^{d}$ The LQ and LS scores of animals given anisomycin plus $\mathbf{P}$ are significantly different from animals given saline plus $P$.

"If cytosol progestin receptor levels are related causally to the sequential inhibition of mating behavior by $P$, then progestin receptors in animals which received anisomycin plus $P$ should not be depleted relative to animals which received saline $+P$. We found, to the contrary, that anisomycin plus $\mathrm{P}$ treatment decreased cytosol progestin receptor levels more than saline plus $\mathrm{P}$ treatment in the MBH-POA.

${ }^{\prime} p<0.001 ;$ Student's $t$ test.

${ }^{\prime} p<0.05$; Student's $t$ test.

thesis by $92 \%$ and $56 \%$ in the hypothalamus $30 \mathrm{~min}$ and $4 \mathrm{hr}$, respectively, after administration (Rainbow et al., 1980 ). In order to test whether protein synthesis is involved in the inhibitory actions of $\mathrm{P}$ which result in "sequential inhibition," we administered anisomycin immediately prior to and again $3 \mathrm{hr}$ after $\mathrm{P}$ or PG treatment. We found that the administration of anisomycin (100 $\mathrm{mg} / \mathrm{kg}$ ) immediately prior to and again $3 \mathrm{hr}$ after $\mathrm{P}(2.5$ $\mathrm{mg}$ ) treatment abolished the "sequential inhibition" of mating behavior at $28 \mathrm{hr}$ (Table I). In animals which received vehicle $(P G)$ injections, the same schedule of anisomycin had no positive or negative effect on LQ or LS scores at $28 \mathrm{hr}$ (Table I). Thus, the abolition of "sequential inhibition" by anisomycin is related to a blockade of progesterone action.

We used anisomycin to demonstrate the time course of the changes in protein synthesis which are essential for the "sequential inhibition" of mating behavior. If a single anisomycin $(100 \mathrm{mg} / \mathrm{kg})$ injection is given $15 \mathrm{~min}$ prior to $\mathrm{P}(2.5 \mathrm{mg})$ administration, "sequential inhibition" of mating behavior is still observed $24 \mathrm{hr}$ later, as measured by the LQ and LS scores (Table II). However, if single anisomycin $(100 \mathrm{mg} / \mathrm{kg})$ injections are given 3 or $9 \mathrm{hr}$ after $\mathrm{P}(2.5 \mathrm{mg})$ administration, "sequential inhibition" of mating behavior is not observed at $24 \mathrm{hr}$ (Table II). At 13 or $17 \mathrm{hr}$ after $\mathrm{P}(2.5 \mathrm{mg})$ administration, single anisomycin injections are no longer effective in abolishing "sequential inhibition" by P (Table II). Since a single anisomycin $(100 \mathrm{mg} / \mathrm{kg})$ injection produces a period of protein synthesis inhibition (50\% or greater) of about 4 $\mathrm{hr}$ in the hypothalamus, these data indicate that a large portion of the protein synthesis which is essential for the inhibition of mating behavior occurs between 3 and $13 \mathrm{hr}$ after the administration of $P(2.5 \mathrm{mg})$.

A decrease in hypothalamic cytosol progestin receptors $24 \mathrm{hr}$ after administration of large doses of $\mathrm{P}$ (e.g., 2.5 $\mathrm{mg}$ ) has been correlated previously with a decreased facilitation of mating behavior at this time, both in the guinea pig (Blaustein and Feder, 1979) and rat (Moguilewsky and Raynaud, 1979; Schwartz et al., 1979; Parsons et al., 1981a). This decrease in cytosol progestin receptor levels $24 \mathrm{hr}$ after $\mathrm{P}$ administration appears to be either a down-regulation of cytosol binding sites by $\mathrm{P}$ or a delay
TABLE II

The effects of anisomycin administration on the sequential inhibition of mating behavior

\begin{tabular}{lrcc}
\hline \multicolumn{1}{c}{ Treatment" } & Number & $\begin{array}{c}\text { Lordosis } \\
\text { Quotient }\end{array}$ & $\begin{array}{c}\text { Lordosis } \\
\text { Quality }\end{array}$ \\
\hline Saline at $0 \mathrm{hr}$ & 10 & $55.0 \pm 6.7$ & $0.80 \pm 0.11$ \\
Anisomycin at $-1 / 4 \mathrm{hr}$ & 6 & $51.7 \pm 11.1$ & $0.78 \pm 0.17$ \\
Anisomycin at $3 \mathrm{hr}$ & 8 & $91.3 \pm 3.0^{\circ}$ & $1.81 \pm 0.10^{h}$ \\
Anisomycin at $9 \mathrm{hr}$ & 6 & $86.7 \pm 2.1^{\mathrm{c}}$ & $1.55 \pm 0.08^{h}$ \\
Anisomycin at $13 \mathrm{hr}$ & 5 & $64.0 \pm 16.9$ & $1.12 \pm 0.32$ \\
Anisomycin at $17 \mathrm{hr}$ & 5 & $55.3 \pm 4.6$ & $0.91 \pm 0.08$ \\
\hline
\end{tabular}

" Treatment administered in addition to $2.5 \mathrm{mg}$ of $\mathrm{P}$ at $0 \mathrm{hr} ; 0.5 \mathrm{mg}$ of $\mathrm{P}$ administered at $24 \mathrm{hr}, 3$ to $4 \mathrm{hr}$ prior to mating test ( $28 \mathrm{hr}$ ).

${ }^{b}$ Significant change from control $(p<0.001$; Student's $t$ test).

"Significant change from control ( $p<0.01$; Student's $t$ test).

in the recycling of the receptor from the nucleus to the cytoplasm (Parsons et al., 1981a). If there is a causal relationship between decreased cytosol progestin receptor levels and the "sequential inhibition" of mating behavior by $\mathrm{P}$, then cytosol progestin levels in animals which have received anisomycin plus $P$ (and which show no behavioral deficit at $24 \mathrm{hr}$ ) should not be depleted relative to animals which have received saline plus $P$ (and which show decreased LQ and LS scores at $24 \mathrm{hr}$ ). We found to the contrary that anisomycin plus $\mathrm{P}$ treatment decreased cytosol progestin receptors in the $\mathrm{MBH}$ POA and pituitary more than saline plus $\mathrm{P}$ treatment (Table I). Although $2.5 \mathrm{mg}$ of $\mathrm{P}$ reduced cytosol progestin receptor levels in MBH-POA and pituitary $24 \mathrm{hr}$ after administration whether anisomycin or saline were concurrently administered, the behavioral and biochemical data obtained with anisomycin plus $\mathrm{P}$ treatment indicate that the reduction in cytosol progestin receptor levels was unrelated to the sequential inhibition of sexual receptivity (Table I). We conclude that the "sequential inhibition" of mating behavior by $\mathbf{P}$ appears to involve an essential step that is not related causally to decreased CPR levels in the hypothalamus or pituitary. It appears that the progesterone-dependent step includes protein synthesis, although strictly speaking, we cannot dismiss possible drug side effects of anisomycin, or other chemical processes, as playing some role (Rainbow et al., 1980). 
Antibiotics have been employed successfully as reversible inhibitors of steroid-induced changes in sexual receptivity and proceptivity (Wallen et al., 1972; Quadagno and Ho, 1975; Rainbow et al., 1980; Parsons et al., 1981b). We have presented evidence elsewhere that a discontinuous estradiol treatment, in two 1-hr segments, is sufficient to activate the lordosis reflex $24 \mathrm{hr}$ after the initiation of estradiol treatment (Parsons et al., 1981b). If anisomycin $(100 \mathrm{mg} / \mathrm{kg})$ is administered immediately before or between these two 1-hr segments of estradiol, almost no receptivity is observed at $24 \mathrm{hr}$; however, if anisomycin is administered after the second segment of estradiol, no behavioral deficit is observed (Parsons et al., 1981b). Anisomycin (100 mg/kg) also has been shown to block selectively and reversibly the facilitation of receptivity and the activation of proceptivity by progesterone (Rainbow et al., 1980). In these studies, it is unlikely that nonspecific debilitating effects of anisomycin were responsible for its selective interference with the activation of sexual behavior. In our present series of experiments, anisomycin was employed to interfere selectively and reversibly with the inhibition of mating behavior by progesterone. Animals which received anisomycin plus $P$ showed increased LQ and LS scores at 24 $\mathrm{hr}$, relative to animals which received saline plus $P$. Similarly, Wallen and co-workers (1972) reported that inhibitory actions of progesterone on mating behavior in guinea pigs could be blocked by intracranial application of cycloheximide. In addition to finding a period of sensitivity to anisomycin, we also found that there were periods of time before ( $-15 \mathrm{~min}$ ) and after (13 and $17 \mathrm{hr}$ ) $P$ administration when anisomycin was ineffective in blocking sequential inhibition. Additionally, we found that, when anisomycin was administered prior to propylene glycol, no positive or negative effects of anisomycin were observed $24 \mathrm{hr}$ later. Our present data, therefore, support the notion that the behavioral effects of anisomycin are related to selective blockade of steroid-induced changes in protein synthesis.

The study of the activation of mating behavior by estradiol has emphasized the role of intracellular receptors that translocate estradiol to the cell nucleus, where the steroid - receptor complex alters gene expression and subsequent protein formation (McEwen et al., 1979). Progesterone also has been shown to be translocated by cytosol receptors to the cell nucleus in brain cells (Blaustein and Feder, 1980). Furthermore, in this paper, we have presented evidence which is consistent with, but not proof of, a model in which the inhibition of mating behavior by progesterone is related to $\mathrm{P}$-induced changes in gene expression and protein synthesis. A large portion of the presumed protein synthesis which is essential for the inhibition of mating behavior occurs between 3 and $13 \mathrm{hr}$ after $\mathrm{P}(2.5 \mathrm{mg})$ administration. Our results indicate that this protein synthesis appears to be dissociated from the reduction in brain and pituitary progestin receptors which also occurs following $\mathrm{P}(2.5 \mathrm{mg})$ administration.

At present, we have no knowledge of the identity of the proteins associated with the inhibition of sexual receptivity by progesterone or of those proteins associated with the facilitation of lordosis by $\mathrm{P}$ (Rainbow et al., 1980). The identification of these proteins, and the manner in which they are intraneuronally integrated to determine whether lordosis occurs, remains a fertile area for future investigation.

\section{References}

Ball, J. (1937) A test for measuring sexual excitability in the female rat. Comp. Psychol. Monogr. 14: 1-37.

Beach, F. A. (1976) Sexual attractivity, proceptivity and receptivity in female animals. Horm. Behav. 7: 105-138.

Blaustein, J. D., and H. H. Feder (1979) Cytoplasmic progestin receptors in female guinea pig brain and their relationship to refractoriness in expression of female sexual behavior. Brain Res. 177: 489-498.

Blaustein, J. D., and H. H. Feder (1980) Nuclear progestin receptors in guinea pig brain measured by an in vitro exchange assay after hormonal treatments that affect lordosis. Endocrinology 106: 1061-1069.

Rlaustein, J. D., and G. N. Wade (1977) Sequential inhibition of sexual behavior by progesterone in female rats: Comparison with a synthetic antiestrogen. J. Comp. Physiol. Psychol. 91: $752-760$.

Boling, J. L., and R. J. Blandau (1937) The estrogen-progesterone induction of mating responses in the spayed female rat. Endocrinology 25: 752-760.

Bradford, M. M. (1976) A rapid and sensitive method for quantification of microgram quantities of protein utilizing the principle of protein-dye binding. Anal. Biochem. 72: 248-254.

Hardy, D. F. (1972) Sexual behavior in continuously cycling rats. Behaviour 41: 288-297.

Hardy, D. F., and J. F. DeBold (1971) The relationship between levels of exogenous hormones and the display of lordosis by the female rat. Horm. Behav. 2: 287-297.

Kubli-Garfias, C., and R. E. Whalen (1977) Induction of lordosis behavior in female rats by intravenous administration of progestins. Horm. Behav. 9: 380-386.

MacLusky, N. J., and B. S. McEwen (1978) Oestrogen modulates progestin receptor concentrations in some brain regions but not in others. Nature 274: 276-277.

MacLusky, N. J., and B. S. McEwen (1980) Progestin receptors in rat brain: Distribution and properties of cytoplasmic progestin binding sites. Endocrinology 106: 192-202.

McEwen, B. S., P. G. Davis, B. Parsons, and D. W. Pfaff (1979) The brain as a target for steroid hormone action. Annu. Rev. Neurosci. 2: 65-112.

McGinnis, M. Y., L. C. Krey, N. J. MacLusky, and B. S. McEwen (1981) Characterization of steroid receptor levels in intact and ovariectomized estrogen-treated rats: An examination of the quantitative, temporal and endocrine factors which influence the neuroendocrine efficacy of an estradiol stimulus. Neuroendocrinology, in press.

Meyerson, B. (1972) Latency between intravenous injection of progestins and the appearance of estrous behavior in estrogen-treated ovariectomized rats. Horm. Behav. 3: 1-9.

Moguilewsky, M., and J. -P. Raynaud (1979) The relevance of hypothalamic and hypophyseal progestin receptor regulation in the induction and inhibition of sexual hehavior in the female rat. Endocrinology 105: 516-522.

Morin, L. (1977) Progesterone: Inhibition of rodent sexual behavior. Physiol. Behav. 18: 701-715.

Parsons, B., N. J. MacLusky, L. Krey, D. W. Pfaff, and B. S. McEwen (1980) The temporal relationship between estrogeninducible progestin receptors in the female rat brain and the time course of estrogen activation of mating behavior. Endocrinology 107: 774-779.

Parsons, B., M. Y. McGinnis, and B. McEwen (1981a) Sequential inhibition by progesterone: Effects on sexual receptivity and associated changes in brain cytosol progestin binding in the female rat. Brain Res., in press.

Parsons, B., T. C. Rainbow, D. W. Pfaff, and B. S. McEwen 
(1981b) Oestradiol, sexual receptivity and cytosol progestin receptors in rat hypothalamus. Nature, in press.

Powers, J. B., and J. Moreines (1976) Progesterone: Examination of its postulated inhibitory actions on lordosis during the rat estrus cycle. Physiol. Behav. 17: 492-498.

Quadagno, D. M., and G. W. K. Ho (1975) The reversible inhibition of steroid-induced sexual behavior by intracranial cycloheximide. Horm. Behav. 6: 19-26.

Rainbow, T. C., P. G. Davis, and B. S. McEwen (1980) Anisomycin inhibits the activation of sexual behavior by estradiol and progesterone. Brain Res. 195: 548-555.

Schwartz, S. M., J. D. Blaustein, and G. N. Wade (1979) Inhibition of estrus behavior by progesterone in rats: Role of neural estrogen and progestin receptors. Endocrinology 105: 1078-1092.

Smith, M. S., M. E. Freeman, and J. D. Neill (1975) The control of progesterone secretion during the estrus cycle and early pseudopregnancy in the rat: Prolactin, gonadotropin and steroid levels associated with rescue of the corpus luteum of pseudopregnancy. Endocrinology 96: 343-349.

Wallen, K., D. A. Goldfoot, W. D. Joslyn, and C. A. Paris (1972) Modification of behavioral estrus in the guinea pig following intracranial cycloheximide. Physiol. Behav. 8: 221-223.

Zucker, I. (1966) Facilitatory and inhibitory effects of progesterone on sexual responses of spayed guinea pigs. J. Comp. Physiol. Psychol. 62: 376-381. 